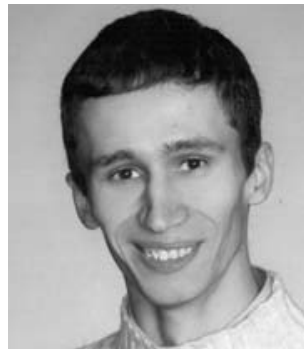

\title{
The Possible Pathological Role of Endogenous Cannabinoid System in Heart Failure Syndrome
}

\author{
(presented at The First International Forum of Young Cardiologists, \\ 1-2 June 2012, Samara, Russian Federation).
}

Introduction. During the last decades the heart failure syndrome has become the area of special interest for pathologists, cardiologists and clinical researchers worldwide. Such interest can be easily explained by four main reasons.

First of all, it is a clinical component. Nowadays, despite the new achievements in our understanding of the etiology, pathophysiology and mechanisms of heart failure progression this syndrome is still associated with a poor prognosis for survival and has a high mortality rates in short- and long time period. New pharmacological and surgical methods of the treatment of heart failure make possible only to achieve a slight decrease in the speed of heart failure progression. However, the prognosis for patients with heart failure is more worth than for patients having malignancies.

Secondary, it is an economic component. It means that managing of patients with heart failure syndrome requires significant financial costs. For example, The National Health Service of The United Kingdom spends approximately $2 \%$ of the general funds on the heart failure management. The major part of these costs relates to hospitalization. Importantly, proven pharmacological therapies make up only a very small proportion of the overall cost of chronic heart failure to the health-care budget in industrialized society [10]. There is no information how much finances are spent on heart failure in Ukraine, but we have to keep in mind that these costs have to be significant enough due to the considered high rates of cardiovascular diseases morbidity among population in general.

Thirdly, it is a social component. Heart failure syndrome for the majority of patients is associated with bad quality of life, longtime periods of physical incapability, bad mental status, and depression, and in severe cases requires life-long nursing help.

Fourthly, it is an epidemiological component. For example, the incidence of heart failure is constantly growing in West European countries and in the United States. Current estimations range between $0.1 \%$ and $0.5 \%$ per year. Among persons aged 75 years and older the incidence of the heart failure exceeds $3 \%$ per year [10]. According to the prognosis the number of patients with heart failure will be continuously rising during the next decades. It can be explained by the better survival rates after several cardiological conditions (first of all, acute myocardial infarction) and also by the population ages.

For changing the situation for better we need a complete understanding of the role of etiological factors for primary heart damage, the role of the risk factors for the development of heart failure, the pathological processes of adaptive and disadaptive character that accompany the heart failure progression.

Historical Aspects. The history of heart failure explorations accurately shows how the new achievements in the understanding of pathological processes that accompanied heart failure syndrome have further resulted in implementation of the new methods of treatment.

The most typical signs of heart failure known from ancient times are edema, lung congestion and breathlessness. So it has resulted in the wide-spread implementation in 
clinical practice of the loop diuretics (for congestion resolving) and glycosides (especially, digoxin). The positive therapeutical effects of these drugs have been well-known since the 18th century. During a long period of time the term 'heart failure' was defined as a syndrome, associated with the disturbance of blood pumping by the heart. As a negative role of renin-angiotensin-aldosterone system activation in the heart failure syndrome was clearly defined the use of angiotensin-converting-enzyme inhibitors and type I angiotensin receptors inhibitors became wide-spread. In the 20th century the experiments in basic sciences showed an important role of the sympathetic nervous system and its mediators in the progression of the heart failure syndrome. The data obtained from the meta-analysis and clinical trials clearly defined the positive role of beta-blocker agents when prescribed for chronic heart failure. This resulted in strong renaissance of beta-blockers in clinical practice. Also, the discovery of the contribution of electrophysiological remodeling in the progressing of the heart failure resulted in the implementation of the cardiac resynchronization therapy in clinical practice.

Nowadays the heart failure definition is evolved to the definition of the heart failure as not just a syndrome of cardiac weakness, but also as a multiple system disorder characterized by abnormalities in the heart, changes in skeletal muscles, kidneys dysfunction, stimulation of the sympathetic nervous system and complex type of neurohumoral changes. Current definition of the heart failure may be presented as a clinical syndrome caused by the disorders of the heart, manifested by characteristic combination of hemodynamic, renal, neurological and hormonal disturbances.

The treatment targeting the different types of neurohumoral systems looks promising direction in the achievement of the therapeutic control over the heart failure progression. This is confirmed by the improved survival rates when using medications that affect the renin-angiotensin-aldosterone system, sympathoadrenal and natriuretic peptide system.

Available data obtained from the scientific researches carried over the past two decades makes us consider a significant pathophysiological role in the pathogenesis of heart failure syndrome of new neurohumoral system the endogenous cannabinoid system $[5,7,9,11]$. This system now appears as a relevant modulator of physiological functions not only in the central nervous system but also in the autonomic nervous system, the endocrine network, the immune system, the gastroin- testinal tract, the reproductive system and in hemodynamic.

Endogenous Cannabinoid System in General. The history of the discovery and study of the endogenous cannabinoid system is closely related with the study of the effects caused by the use of hashish, marijuana and other cannabis products.

The first mention of the use of cannabis for medical purposes refers to the third millennium BC in the description of medicinal plants during the reign of the Chinese Emperor Cheng Nang. Around 500 BC Assyrian records referred to the cannabis as an effective remedy for pain relief. In $60 \mathrm{BC}$, the medicinal properties of cannabis were described in the Pharmacopoeia of the Roman military doctor Dioskorides, who lived during the reign of Emperor Claudius and Nero. In 1597 John Gerard in England recommended the use of cannabis as an analgesic for ear pain and Nicholas Culpeper in 1653 - for the treatment of joint inflammation in gout.

Scientific interest in the study of mechanisms of cannabis influence on human body renewed in the 60 -ies of the last century. The endogenous cannabinoid system is a ubiquitous lipid signaling system that appeared early in the evolution and which has important regulatory functions throughout the body. It was found that the main component of the cannabis that causes a number of specific psycho-emotional effects is delta-9tetrahydrocannabiol (THC) [9]. It is a lipophylic compound with a slow rate of metabolism in the liver. However, for more than 20 years the mechanisms of THC interaction with the structures of the brain have been a secret for researchers. In 1988 Ellin Haulett from the University of St. Louis, using the method of radioactive carbon labels established the interaction of a metabolite of THC with the specific receptors of the brain of mice. This gave rise to further studies and in 1990 was identified and described the structure of cannabinoid receptor type 1 (CB1). Two years later the cannabinoid receptor type 2 (CB2) was identified. Due to the well-established psychological effects of cannabis components at first the majority of experiments on cannabis were performed for determination of the possible positive therapeutical effects on brain structures and only in the last years the effects of the endogenous cannabinoid system for cardiovascular system were reported.

Receptors and mediators. Both CB1 and CB2 receptors relate to the family of G-protein coupled receptors. CB1 is a complex 
structure presented by the seven transmembrane domains that permeate a cell membrane and are closely associated with the several intracellular signaling systems (see Pict. №1). The activation of CB-1 results in activating the intracellular cascade of complex signaling biochemical reactions, that changes the permeability of transmembrane ion channels, such as calcium (inactivation) and potassium (activation). CB1 receptors are predominantly localized in central nervous system, but also were found in ganglia of autonomic nervous system, pituitary gland, adrenal glands, heart, vessels endothelium, gastrointestinal system, urine bladder, immune cells. It is also found that CB1 localized in the vascular wall, by controlling the L-type calcium ion channels, can cause strong vasodilation. CB1

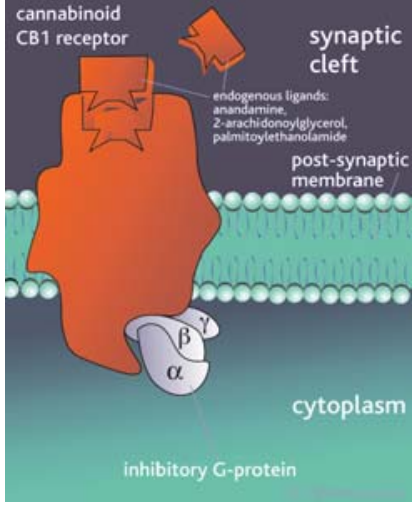

Picture 1

The Structure of CB1-receptor

(from the

www.cnsforum.com)

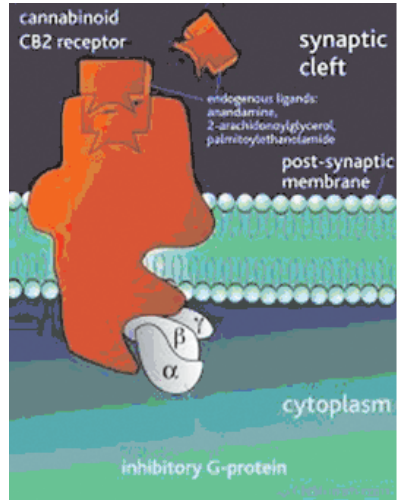

Picture 2

The Structure of CB2-receptor

(from the

www.cnsforum.com) receptors located on nerve endings (postsynaptic) modulate the release of excitatory and inhibitory neurotransmitters, thus adjusting the intensity of the signals [12].

CB2 receptor has a similar structure to CB1, but slightly differs in components. CB2 receptors localize in lymphoid tissues and macrophages and are absent in the central nervous system. The main effect of stimulation of CB2 is immunosuppression.

The principles of CB1 and CB2 functioning are similar. Activation of the receptor leads to the inhibition of adenylatcyclase and stimulation of mitogen-activating proteinkinase, thus providing the control of intracellular functions. CB1 and CB2 receptors are negatively coupled to adenylate cyclase through $\mathrm{Gi} / \mathrm{o}$ proteins, but can also signal via protein kinases $\mathrm{A}$ and $\mathrm{C}$, mitogen-activated protein kinases, and cyclooxygenase 2 pathways, among others. First of all it results in inactivation of calcium ion channels and activation of potassium ion channels.

Nowadays, two endogenous ligands are considered to provide a typicall regulation of CB1 and CB2 functioning - 2-arachydonylglycerin and arachydonylethanolamide (anandamide).

In 1992 the first putative endocannabinoid was identified from porcine brain. This ligand was later called anandamide, which is derived from the Sanskrit word for bliss (ananda) due to its possible cannabimimetic, psychotropic properties.

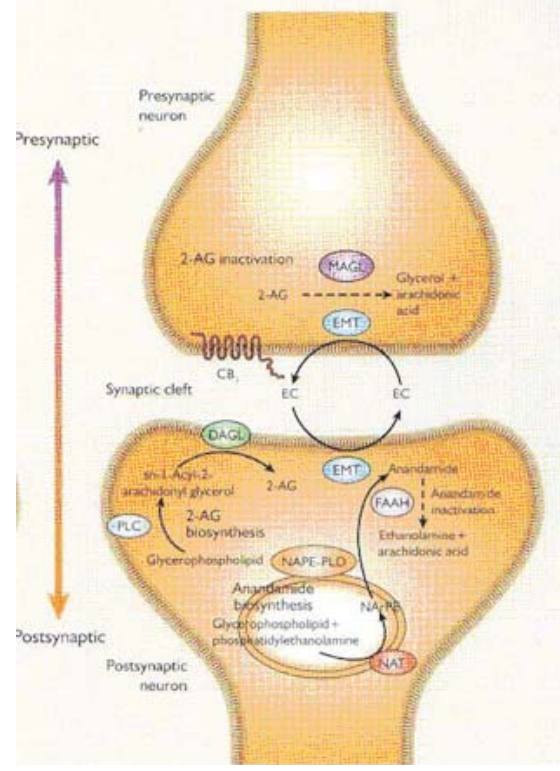

Picture 3. The Metabolism Of Endogenous Cannabinoid Ligands In Neuronal Synapse (from the Cefalu.W., Cannon Ch., "Atlas of Cardiometabolic Risk", Informa Healthcare

Anandamide is generated by the transacytalation of membrane phosphatidylethanolamine to yield $\mathrm{N}$-arachidonoyl phophatidylethanolamin, which is then hydrolyzed into arachidonoyl ethanolamide. 2-arachydonylglycerin is formed from glycerophospholipids by the actions of phospholipase C. Endocannabinoids are cleared from the extracellular space by cellular uptake through a putative membrane transporter, followed by enzymatic degradation (see Pict. 3).

2-arachydonylglycerin binds to both CB1 and CB2 receptors, whereas anandamid has higher affinity for CB1 receptors and may also bind to vanilloid VR1 receptors. The important feature of these mediators is the fact that they are predominantly released "on demand". In the case of stress of any origin (especially in shock cases) mediators are synthesized for normalisation of such general functions as energy balance, homeostasis, analgesia and haemodynamic. The tissue levels of endocannabinoids are determined by the balance between their biosynthesis (involving phospholipase D and diacylglycerol lipasedependent and other pathways), cellular uptake, and degradation by fatty acid amide hydrolase and/or monoacylglycerol lipases.

Heart failure syndrome can be considered as stress state as it accompanies with strong 
activation of compensatory and adaptative resources.

Endogenous cannabinoid system and hemodynamic regulation. The first scientific publications appeared in 60 -ies of the 20th century, but major advances in understanding of the endogenous cannabinoid effects on hemodynamic regulation have been obtained in last 15 years [14].

Despite the great diversity of the effects caused by endogenous cannabinoid substances that affect $\mathrm{CB} 1$ receptors the most typical effects are:

- Negative chronotropic effect

- Negative inotropic effect

- Antiatherosclerotic

- Antiarrhytmic

- Stimulation of the cirrhotic process in liver.

As noted by Siquiera et al. in 1979 intravenous administration of the anandamide in rats caused marked bradycardia. Also it was reported the three-phase reaction in blood pressure when anandamide was administered in parenteral rout $[6,15]$. The first phase rapid lowering of the blood pressure, the second - a short-term stabilization with a slight elevation of blood pressure, the third marked progressive fall in blood pressure. The concomitant administration of atropine was found to lose the first phase, but the steady fall in blood pressure (3rd phase) was observed in all experiments despite the atropine influence This led to the formulation of an explanation that these changes in blood pressure of the third phase, certainly are due to the activation of the CB1 receptors and are independent of the sympathetic nervous system. Experiments by Batkai et al. in 2004 demonstrated that anandamide associated hypotensive response can be explained by two mechanisms - by the decrease of peripheral vascular resistance and by the decrease in inotropic function of the heart [2]. Thus the introduction of the selective experimental antagonist of the CB1 receptors - SR141716, completely eliminates these hemodynamic effects. It confirms the approved hypothesis [2].

As CB-1 receptors in their functioning are closely related to the functioning of potassium and calcium ion channels, as this haemodynamic responses on $\mathrm{CB} 1$ activation can be explained in such ways:

- the stimulation of the $\mathrm{CB} 1$ receptors localized in the walls of blood vessels causes inactivation of calcium ion channels that leads to vasodilation and reduced peripheral vascular resistance, followed by the fall of blood pressure [8,17];

- the stimulation of the CB1 receptors localized in heart results in inactivation of the calcium ion channels that further reduces the transmembrane calcium flow and thus reduces inotropic function of the heart. The negative inotropic effect was also observed for atriums [3, 4];

- the stimulation of the CB1 receptors localized in heart results in potassium ion channels activation and leads to bradycardia.

Also the effects of endogenous cannabinoid system regulation are realized via central nervous system. Both sympathetic and parasympathetic nerve terminals have presynaptic CB1 receptors, stimulation of which suppresses norepinephrine and acetylcholine release respectively.

Incidentally, do not forget about the role of sympathoadrenal system as a compensatory regulator in heart failure syndrome as the effects of its stimulation could overlap and reverse the effects of stimulation of peripheral CB1 receptors.

So we have to expect that several pathological processes in heart failure syndrome are the consequences of endogenous cannabinoid system influence on the hemodynamic:

1. For the majority of patients with the end-stage heart failure a strong and progressive loss of appetite and weight are observed. There are no doubt that this fact can be explained by impaired liver function as the phenomena of "congestion liver," but this is probably also due to the hyperactivation of endogenous cannabinoid system. As its known, the activation of cannabinoid system due to the activation of CB1 receptors causes an increase in appetite, changes in metabolism of adipose tissue and further leads to obesity. The drug rimonabant was studied as a central cannabinoid receptor blocker as blocking the CB1 receptors that results in the loss of appetite and weight [16]. Heart failure is a condition associated with the hyperstimulation of cannabinoid receptors and $\backslash$ or the depletion of effects of the mediators on them, which leads to loss of appetite and weight [13].

2. Heart failure is associated with the development of abnormal liver function, elevated liver enzymes and progressive fibrosis process in liver. Also the hyperactivation with further depletion of CB1 is strongly related with the progressive cirrhotic process in the liver as it was observed in several experiments on mice [1].

3. Depression. For most patients with the high functional class of heart failure the development of depression is usually observed. According to the own observations, among the patients with heart failure NYHA I the depression rate is not more than 5,0\%, 
in NYHA II - 12,0 \% in NYHA III - 40,0\%, in NYHA IV - up to $70,0 \%$. Theoretically, this could be due to hyperactivation and further depletion of CB1 stimulation in the central nervous system, as its known that stimulation of the CB1 causes euphoria, inhibition/depletion leads to depression.
4. Pain. The acute decompensation of chronic heart failure does not often accompany the patients' complaints on pain of muscular origin. CB1 receptor activation is known to lead to stable analgesia, inhibition/depletion - to the pain.

\section{References}

1. Bátkai S., Jarai Z., Wagner J.A., Goparaju S.K., Varga K., Liu J. et al. Endocannabinoids acting at vascular CB1 receptors mediate the vasodilated state in advanced liver cirrhosis// Nat. Med. - 2001. - Vol. 7. - P. 827-832.

2. Bátkai S., Pacher P., Jarai Z., Wagner J. A., Kunos G. Cannabinoid antagonist SR-141716 inhibits endotoxic hypotension by a cardiac mechanism not involving CB1 or CB2 receptors// Am. J. Physiol. Heart Circ. Physiol. -2004 a. - Vol. 287. - P. 595-600.

3. Bilfinger T. V., Salzet M., Fimiani C., Deutsch D. G., Tramu G., Stefano G. B. Pharmacological evidence for anandamide amidase in human cardiac and vascular tissues. Int. J. Cardiol.// 1998. - Vol. 64, Suppl 1. - P. 15-22.

4. Bonz A., Laser M., Kullmer S., Kniesch S., Babin-Ebell J., Popp V. et al. Cannabinoids acting on CB1 receptors decrease contractile performance in human atrial muscle// J. Cardiovasc. Pharmacol. - 2003. - Vol. 41. P. 657-664.

5. Cannon C.P. The endocannabinoid system: a new approach to control cardiovascular disease// Clin. Cornerstone. -2005 . - V. 7. - P. 17-26.

6. Garc?a M.C., Adler-Graschinsky E., Celuch S. M. Hypotensive effect of anandamide through the activation of CB1 and VR1 spinal receptors in urethane-anesthetized rats Naunyn Schmiedebergs// Arch. Pharmacol. - 2003. - Vol. 368. - P. 270-276.

7. Hiley C. R., Ford W. R. Cannabinoid pharmacology in the cardiovascular system: potential protective mechanisms through lipid signaling// Biol. Rev. Camb. Philos. Soc. - 2004. - Vol. 79. - P. 187-205.

8. Hillard C. J. Endocannabinoids and vascular function// J. Pharmacol. Exp. Ther. - 2000. - Vol. 294. - P. 27-32.

9. Jones R. T. Cardiovascular system effects of marijuana. // J. Clin. Pharmacol. -2002, - Vol. 2. - P. 58S-63S.

10. Kearney Mark. Chronic Heart failure. Oxford Univercity Press, 2008. - P. 6-7.

11. Kunos G., Jarai Z., Batkai S., Goparaju S.K., Ishac E.J., Liu J. et al. Endocannabinoids as cardiovascular modulators // Chem. Phys. Lipids. - 2000. - Vol. 108. - P. 159-168.

12. Matsuda L. A., Lolait S. J., Brownstein M.-J., Young A.-C., Bonner T.-I. Structure of a cannabinoid receptor and functional expression of the cloned cDNA// Nature. - 1990. - Vol. 346. - P. 561-564.

13. Osei-Hyiaman D., Harvey-White J., Batkai S., Kunos G. The role of the endocannabinoid system in the control of energy homeostasis// Int. J. Obes. (London). - 2006. - Vol. 30. - P. 33-38.

14. Randall M. D., Harris D., Kendall D. A., Ralevic V. Cardiovascular effects of cannabinoids// Pharmacol Ther. - 2002. - Vol. 95. - P. 191-202.

15. Siqueira S.W., Lapa A.P., Ribeiro do Valle J. The triple effect induced by delta 9-tetrahydrocannabinol on the rat blood pressure// Eur. J. Pharmacol. - 1979. - Vol. 58. - P. 351-357.

16. Tonstad S. Rimonabant: a cannabinoid receptor blocker for the treatment of metabolic and cardiovascular risk factors// Nutr. Metab. Cardiovasc. Dis. 2006. - Vol. 16. - P.156-162.

17. Wagner J.A., Jarai Z., Batkai S., Kunos G. Hemodynamic effects of cannabinoids: coronary and cerebral vasodilation mediated by cannabinoid $\mathrm{CB}(1)$ receptors// Eur. J. Pharmacol. - 2001a. - Vol. 423. - P. $203-210$.

Стаття надійшла до редакції журналу 24.12.2012 p.

\section{The Possible Pathological Role of Endogenous Cannabinoid System in Heart Failure Syndrome}

\section{O. Katerenchuk}

Heart failure is a clinical syndrome associated with the high rates of short-time and long-time mortality. The pathological role of several neurohumoral systems is well-established in heart failure progression. According to the data available from the basic experiments the role of the endogenous cannabinoid system in heart failure progression is considered. The hyperstimulation with further depletion of CB1 receptors and mediators results in hypotension, bradycardia, depression, muscle pain and liver cirrhosis - that usually accompanies the decompensated and end-stage heart failure. Further discovering of CB1 exogenous agents acting on central nervous system and/or peripheral CB1 receptors can result in creating the new group of drugs in heart failure treatment.

Key words: endogenous cannabinoid system, heart failure, treatment. 


\section{Можлива патологічна роль ендогенної канабіноїдної системи в синдромі серцевої недостатності}

\section{O. I. Катеренчук}

Серцева недостатність - клінічний синдром, пов'язаний з високими показниками смертності в коротко- та довготривалий період часу. Патофізіологічна роль низки нейрогуморальних систем у випадку серцевої недостатності чітко визначена. Згідно з отриманими результатами експериментів $\epsilon$ підстави вважати наявність впливу ендоґенної канабіноїдної системи на прогресування серцевої недостатності. Гіперстимуляція з подальшим виснаженням активності CB1-рецепторів і медіаторів призводить до гіпотензії, брадикардії, депресії, м'язового болю та циротичних змін печінки, що характерно для декомпенсованої та термінальної серцевої недостатності. Подальше вивчення екзоґенних препаратів, що впливають на центральні та периферійні СВ1-рецептори, сприятиме створенню нової групи препаратів у лікуванні серцевої недостатності.

Ключові слова: ендоґенна канабіноїдна система, серцева недостатність, лікування. 